\title{
CHANGES OF POLYPHENOL COMPOUND CONCENTRATIONS IN HYBRIDS OF NANTE TYPE CARROTS DURING STORAGE
}

\author{
Ingrīda Augšpole, Tatjana Kince, and Ingmārs Cinkmanis \\ Faculty of Food Technology, Latvia University of Agriculture, 22 Rīgas Str., Jelgava, LV-3001, LATVIA \\ Corresponding author, ingrida.augspole@ Ilu.Iv
}

Communicated by Andris Ozols

\begin{abstract}
The main purpose of the study was to determine changes of polyphenol concentrations in hybrids of Nante type carrots during storage. Fresh Nante type 'Forto' variety carrots and carrot hybrids 'Bolero' F1, 'Champion' F1, and 'Maestro' F1 were cultivated in the Zemgale region of Latvia. Carrots were stored for six months in air $\left(+3 \pm 1{ }^{\circ} \mathrm{C}, \mathrm{RH}=89 \pm 1 \%\right)$ and polyphenol compound concentrations were determined at two month intervals. High-performance liquid chromatography was used to determine concentrations of eight polyphenols in carrots: gallic acid, catechin, epicatechin, caffeic acid, chlorogenic acid, ferulic acid, vanillin, and rutin. Significant differences occurred in polyphenol concentrations of fresh Nante type variety 'Forto' carrots and several hybrids ('Bolero' F1, 'Champion' F1, and 'Maestro' F1) during storage. After six months of storage, the concentration of polyphenol compounds of Nante type carrots decreased - caffeic acid by $64.6 \%$, chlorogenic acid - by $37.9 \%$ and vanillin - by $81.5 \%$. However, during storage, concentration of some polyphenol compounds increased, as catechin by $30.5 \%$, epicatechin by $85.2 \%$, gallic acid by $48.5 \%$ and ferulic acid by $87.9 \%$.
\end{abstract}

Key words: carrots, polyphenols compounds, storage.

\section{INTRODUCTION}

Carrot (Daucus carota L.) is among the top-ten most economically important vegetable crops in the world, in terms of both area of production and market value (Prohens and Nuez, 2008). Carrot is a good source of natural antioxidants, especially carotenoids and phenolic compounds (Chantaro et al., 2008). The presence of phenolic compounds in carrots contributes to their sensory qualities, like colour, bitterness, and aroma. Therefore, phenolic compound concentration can be used as a good indicator to evaluate vegetable quality during processing and storage (Goncalves et al., 2010). Phenolics are iniquitous secondary metabolites in plant. They comprise a large group of biologically active ingredients - from simple phenol molecules to polymeric structures with molecular mass above 30000 Ds. On the basis of the number of phenol subunits, the modern classification forms two basic groups of phenolics simple phenols and polyphenols. The group of simple phenols contains also the so-called "phenolic acids" or phenols with a carboxyl group determining their specific function (Marinova et al., 2005). The common feature of plant phenolic compounds is the presence of a hydroxy-substituted benzene ring within their structure. They may be classified into different groups as a function of the number of phenol rings contained and the structural elements that bind these rings to one another. Distinctions are thus made between the flavonoids, phenolic acids, stilbenes, and lignans. These compounds occur primarily in conjugated form, with one or more sugar residues linked to hydroxyl groups, although direct linkages of the sugar unit to an aromatic carbon atom also exist. Associations with other compounds, such as organic acids, amines and lipids, and linkages with other phenols are also common (Vladimir-Knežević et al., 2012). Major phenols in carrots include chlorogenic, caffeic, and p-hydroxybenzoic acids along with numerous cinnamic acid derivatives. Different carrot tissues have similar composition, but their phenolic concentration differs, decreasing from the exterior (peel) to the interior (xylem). Moreover, the reported concentration may vary with the extraction method, the way to expressing the results, and other factors such as cultivars, post-harvest and processing conditions (Goncalves et al., 2010). Recently, Alasalvar et al. (2002) reported that orange, purple, yellow and white carrot varieties contain mainly hydroxycinnamic acid derivatives 3'-Caffeoylquinic acid (neochlorogenic acid), 5'-Caffeoylquinic acid (chlorogenic acid), 3'-, 4'- and 5'-Feruoylquinic acids, $3^{\prime}$ - and 5'-p-Coumaroylquinic acids, $3^{\prime}, 4^{\prime}-$ and 3',5'-Dicaffeoylquinic acids 3',4'- and 3',5'-Diferuoylquinic acids (Alasalvar et al., 2002). Cell wall material also contains small amounts of vanillic, p-coumaric, trans- and cis-ferulic acids as well as phydroxybenzaldehyde and 
vanillin (Shahidi and Naczk, 2004). Plant phenolics exhibit a range of biological activities in vitro, which supports their contribution to the beneficial effects of fruit- and vegetable-rich diets. Indeed, there is reasonable evidence from epidemiological studies to support the notion that diets rich with phenolics (derived from fruits and vegetables) are associated with lower risks of cancer, osteoporosis, cardiovascular diseases, cataracts, and diseases associated with brain and immune dysfunction (Watson, 2000; Goncalves et al., 2010). Polyphenols bound in the food indigestible fraction can account for a substantial part of total phenolic compounds in foods. While a minor part of dietary polyphenols can be absorbed in the small intestine, most dietary polyphenols are not bioavailable in the human upper intestine and may exert biological activity through the intestinal tract (Hervert-Hernández et al., 2011). Furthermore, phenolic compounds, which constitute the active substances found in commonly used medicinal plant extracts, modulate the activity of a wide range of enzymes and cell receptors. Various dietary phenolics such as caffeic acid, silibinin, curcumin, and various flavonoids may also be important in anti-inflammatory actions (Daayf and Lattanzio, 2008). There is considerable current interest in plant phenolics and their potential to beneficially affect human health (Daayf and Lattanzio, 2008).

The aim of the study was to evaluate changes in polyphenol compound concentrations in hybrids of Nante carrots changes during storage.

\section{MATERIALS AND METHODS}

Experiments were carried out in the Department of Food Technology at the Latvia University of Agriculture. The research was conducted on carrots (Daucus carota L.) grown and harvested in Latvia in the Zemgale region. Fresh Nante type 'Forto' variety carrots and carrot hybrids 'Bolero' F1, 'Champion' F1, and 'Maestro' F1 were analysed immediately after harvesting; carrots were stored for six months in air $\left(+3 \pm 1{ }^{\circ} \mathrm{C}, \mathrm{RH}=89 \pm 1 \%\right)$ and their concentration of polyphenols was determined every two months.

Phenolic compounds. The analysis of polyphenols was performed with a Shimadzu HPLC system LC-20 Prominence including Photo-diode Array detector SPD-M20A, Solvent Delivery Unit LC-20AD, Column Oven CTO-20A, Autosampler SIL-20A, System Controller CBM-20A and data system LCsolution software.

The calibration solution was prepared in a $100 \mathrm{~mL}$ volumetric flask with narrow neck by adding $6.8 \pm 0.1 \mathrm{mg}$ gallic acid, $12.0 \pm 0.1 \mathrm{mg}$ catechin, $13.1 \pm 0.1 \mathrm{mg}$ chlorogenic acid, $13.8 \pm 0.1 \mathrm{mg}$ caffeic acid, $16.0 \pm 0.1 \mathrm{mg}$ epicatechin, $9.8 \pm$ $0.1 \mathrm{mg}$ vanillin, $9.2 \pm 0.1 \mathrm{mg}$ ferulic acid, $6.1 \pm 0.1 \mathrm{mg}$ rutin, and filling with HPLC grade CHROMASOLV® methanol till mark and mixing.

Chromatography. An analytical column PerkinElmer C18 of dimensions $4.6 \mathrm{~mm} \times 250 \mathrm{~mm}, 5 \mu \mathrm{m}$ and temperature
$+30{ }^{\circ} \mathrm{C}$ was used for separation of polyphenols at wavelength $278 \mathrm{~nm}$. Injection volume of a sample was $100 \mu \mathrm{L}$. The mobile phase consisted of A (deionised water), B (HPLC grade CHROMASOLV ${ }^{\circledR}$ methanol) and C (Acetic acid solution for HPLC) in the gradient conditions. Start flow rate was $1.0 \mathrm{~mL} \mathrm{~min}^{-1}$ (Priecina et al., 2015).

Statistical analysis. Data were expressed as mean \pm standard deviation; for mathematical data processing the value of $p<0.05$ was regarded as statistically significant. One-way analysis of variance (ANOVA) was used to determine the significance of differences. In case of significant differences, homogeneous groups were determined by the Tukey's multiple comparison test at the level of confidence $\alpha=0.05$. The statistical analyses were performed using Microsoft Excel 2010.

\section{RESULTS}

Higher polyphenol compound concentration was found in 'Forto' variety carrots, indicating high nutritional value of the variety and positive affect on human health. The lowest polyphenol compound concentration was found in hybrid 'Maestro' F1 (Fig. 1). The polyphenol compound concentration of Nante carrots differed after six months of storage depending on variety and hybrid ( $p=0.004 ; \alpha=0.05)$. There was a significant increase of polyphenol concentration in carrots during six month storage: catechin concentration by $30.45 \%$, epicatechin by $85.22 \%$, gallic acid by $48.54 \%$, and ferulic acid by $87.87 \%$. Storing carrots in air for more than two months resulted in transfomation of polyphenols, which can be explained by decrease in concentration of one polyphenol compound content an increases of another.

Concentration of vanillin, chlorogenic acid, rutin, and caffeic acid decreased during the storage period in Nante varieties and hybrids $(p=0.02 ; \alpha=0.05)$. After six months of carrot storage, the caffeic acid concentration decreased by $64.64 \%$, chlorogenic acid by $37.95 \%$, and vanillin by

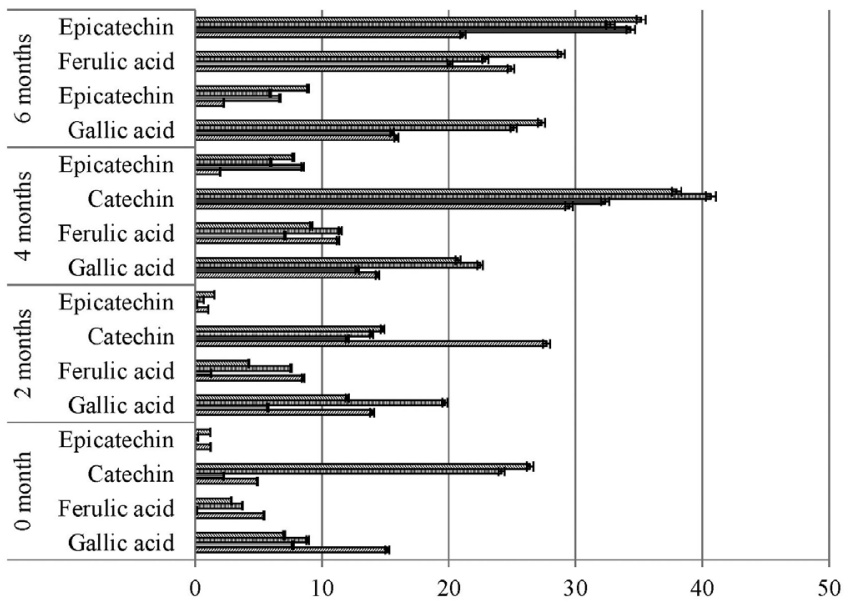

Polyphenol concentration, $\mathrm{mg} 100 \mathrm{~g}^{-1}$ dry matter

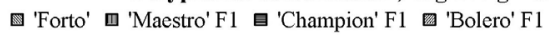

Fig. 1. Changes of polyphenols concentration in carrots during storage. 


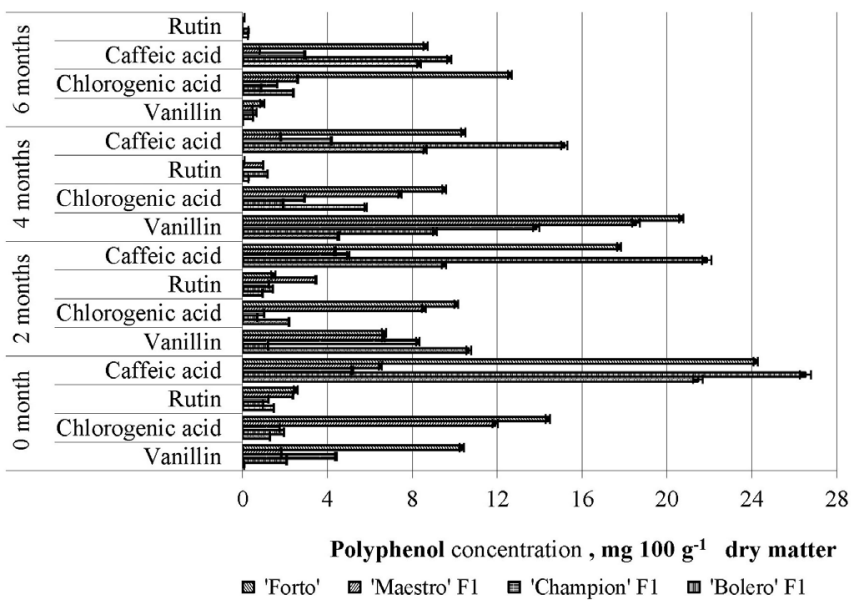

Fig. 2. Dynamics of polyphenols concentration in carrots during storage.

$81.49 \%$. Rutin concentration after six months of storage in hybrid 'Bolero' F1 carrots decreased by $70.83 \%$, while in the other carrots varieties rutin was not identified (Fig. 2).

\section{DISCUSSION}

In carrots polyphenol compound impart sensory properties such as colour, bitterness, flavour, and rheological properties. Polyphenol compounds increase the nutritional value of carrots and ensure their antioxidant properties (Balasundram et al., 2006; Goncalves et al., 2010; O'Shea et al., 2013). The increase of polyphenol concentration differs depending on properties of carrot varieties and genotypes (Lamikanra, 2002; Alasalvar et al., 2005; Smoleń and Sady, 2009). Polyphenol compounds easily oxidise during storage in oxygen (Manach et al., 2004). Oxidation results in a decrease of the amount of polyphenols in carrots. Decrease of polyphenol concentration in carrots during storage can be attributed to biodegradation processes stimulated by microorganisms (Fraga, 2009).

The study on polyphenol compounds of fresh Nante type variety 'Forto' carrots and several hybrids ('Bolero' F1, 'Champion' F1 and 'Maestro' F1) after harvest and during storage revealed a significant difference in polyphenol concentrations. After six months of storage, the concentration of polyphenol compounds of Nante type carrots decreased - caffeic acid by $64.6 \%$, chlorogenic acid by $37.9 \%$, and vanillin by $81.5 \%$. However, during storage the concentration of some polyphenol increased: catechin by $30.5 \%$, epicatechin by $85.2 \%$, gallic acid by $48.5 \%$ and ferulic acid by $87.9 \%$.

\section{REFERENCES}

Alasalvar, C., Al-Farsi, M., Quantick, P. C., Shahidi, F., Wiktorowicz, R. (2005). Effect of chill storage and modified atmosphere packaging (MAP) on antioxidant activity, anthocyanins, carotenoids, phenolics, and sensory quality of ready-to-eat shredded orange and purple carrots. J. Food Chem., 89, 69-76.

Alasalvar, C., Grigor, J. M., Zhang, D., Quantick, P. C., Shahidi, F. (2002) Comparison of volatiles, phenolics, sugars, antioxidant vitamins, and sensory quality of different colored carrot varieties. J. Agric. Food Chem., 49 (3), 1410-1416.

Balasundram, N., Sundram, K., Samman, S. (2006). Phenolic compounds in plants and agri-industrial by-products: Antioxidant activity, occurrence, and potential uses. J. Food Chem., 99 (1), 191-203.

Chantaro, P., Devahastin S., Chiewchan, N. (2008). Production of antioxidant high dietary fiber powder from carrot peels. J. Food Sci. Technol., 41, 1987-1994.

Daayf, F., Lattanzio, V. (2008). Recent Advances in Polyphenol Research. Vol. 1. Wiley-Blackwell. 437 pp.

Fraga, C. G. (2009). Plant Phenolics and Human Health: Biochemistry, Nutrition, and Pharmacology. John Wiley and Sons, Hoboken. 593 pp. (at p. 475).

Goncalves, E. M., Pinheiro, J., Abreu, M., Brandao, T. R. S., Silva, C. L. M. (2010). Carrot (Daucus carota L.) peroxidase inactivation, phenolic content and physical changes kinetics due to blanching. J. Food Eng., 97, 574-581.

Hervert-Hernández, D., García, O. P., Rosado, J. L., Gońi, I. (2011). The contribution of fruits and vegetables to dietary intake of polyphenols and antioxidant capacity in a Mexican rural diet: Importance of fruit and vegetable variety. Food Res. Int., 44 (5), 1182-1189.

Berregi, I., Santos, J. I., Campo, G., Miranda, J. I. (2003). Quantitative determination of (-)-Epicatechin in cider apple juice by HNMR. J. Talanta, 62 (1), 139-145,

Lamikanra, O. (2002). Fresh-cut Fruits and Vegetables: Science, Technology, and Market. CRC PRESS, Boca Raton. 480 pp. (at p. 467).

Manach, C., Scalbert, A., Morand, C., Rémésy, C., Jimenez, L. (2004). Polyphenols: Food sources and bioavailability. Amer. J. Clin. Nutr., 79, 727-747.

Marinova, D., Ribarova, F., Atanassova, M. (2005). Total phenolics and total flavonoids in Bulgarian fruits and vegetables. J. Univ. Chem. Technol. Metallurgy, 40 (3), 255-260.

O'Shea, N., Arendt, E. K., Gallagher, E. (2013). Dietary fibre and phytochemical characteristics of fruit and vegetable by-products and their recent applications as novel ingredients in food products. Food Nutr. Res., 1 (3), 13-23.

Priecina, L., Karklina, D., Cinkmanis, I. (2015). Phenolic compounds in fresh and processed vegetables and spices. Ann. Nutr. Metab., 12th European Nutrition Conference, 67 (1), 476.

Prohens, J., Nuez, F. (2008). Vegetables II: Fabaceae, Liliaceae, Solanaceae, and Umbelliferae. Springer, Valencia. 365 pp.

Shahidi, F., Naczk, M. (2004). Phenolics in Food and Nutraceuticals. CRC PRESS, Boca Raton. 566 pp.

Smoleń, S, Sady, W. (2009). The effect of various nitrogen fertilization and foliar nutrition regimes on the concentrations of sugars, carotenoids and phenolic compounds in carrot (Daucus carota L.). Sci. Horticult., 120 (3), 315-324.

Vladimir-Knežević, S., Blažeković, B., Štefan, M. B., Babac, M. (2012). Plant polyphenols as antioxidants influencing the human health. In: Venketeshwer Rao (Ed.). Phytochemicals as Nutraceuticals - Global Approaches to Their Role in Nutrition and Health. Rijeka, Croatia, pp. 155-180.

Watson, I., Tan, B. K., Armstrong, G., Stewart-Tull, D., Marshall, R. (2007). Shelf life extension of carrots and potatoes: A comparison of $\mathrm{H}_{2} \mathrm{O}_{2}$, laser, $\mathrm{UV}$, and microwave treatments. In: IOA Conference and Exhibition, Valencia, Spain, 29-31 October 2007. Vol. 5.13, pp. 1-14. 


\section{POLIFENOLU SAVIENOJUMU IZMAIṆAS UZGLABĀŠANAS LAIKĀ NANTE TIPA BURKĀNOS}

Pētījuma mērķis bija noteikt un izvērtēt vēlās Nante tipa 'Forto’ šķirnes burkānu un burkānu hibrīdu ‘Bolero' F1, ‘Champion' F1 un 'Maestro’ F1 polifenolu savienojumus (gallusskābi, katehīnu, epikatehīnu, kafijskābi, vanilīnu, hlorogēnskābi, epikatehīnu, ferulskābi un rutīnu) pēc ražas novākšanas tradicionālajos uzglabāšanas apstākḷlos. Burkāni tika uzglabāti sešus mēnešus gaisa vidē $3 \pm 1{ }^{\circ} \mathrm{C}$ temperatūrā, $89 \pm$ $1 \%$ relatīvā gaisa mitrumā. Polifenolu savienojumu izmainas tika noteiktas, izmantojot augsti efektīvo šķidruma hromatogrāfu (HPLC SHIMADZU LC-20AD Prominence, Japāna). Polifenolu savienojumu saturs Nante tipa škirnes un to hibrīdu burkānos pēc sešu mēnešu uzglabāšanas būtiski atškīinās $(p=0,004 ; \alpha=0,05)$. Pētītajos burkānos līdz sestajam uzglabāšanas mēnesim palielinājās katehīna saturs — vidēji par 30,45\%, epikatehīns par 85,22\%, gallusskābe vidēji par 48,54\%, ferulskābe vidēji par 87,87\%. Vanilīns, hlorogēnskābe, rutīns un kafijskābe Nante tipa šķirnes un to hibrīdu burkānos uzglabāšanas laikā būtiski samazinājās $(p=0,02 ; \alpha=0,05)$. Pēc sešiem uzglabāšanas mēnešiem kafijskābes saturs samazinājās par $64,64 \%$, hlorogēnskābes par 37,95\%, vanilīna par 81,49\%. Savukārt rutīna saturs pēc sešu mēnešu uzglabāšanas hibrīda 'Bolero' F1 burkānos samazinājās par 70,83\%, bet pārējos analizētajos burkānos to identificēt neizdevās. Pētījumā iegūtie rezultāti sniedz pārskatu par Latvijā audzētu burkānu polifenolu savienojumu sastāvu un to izmaiṇām uzglabāšanas laikā, tādējādi norādot uz burkānu augsto uzturvērtību. 